\title{
Islamic CALLigraphy
}





\section{Islamic Calligraphy}

Sheila S. Blair 
(c) Sheila S. Blair, 2006, 2008

First published in 2006 by

Edinburgh University Press Ltd

22 George Square, Edinburgh

Reprinted 2007

This paperback edition 2008

Reprinted 2018

Typeset in Io/I 2 pt Trump Mediaeval by

Servis Filmsetting Ltd, Stockport, Cheshire, and printed and bound in the UK by

P2D Ltd by arrangement with Associated Agencies Ltd, Oxford

A CIP record for this book is available from the British Library

ISBN 9780748635405 (paperback)

The right of Sheila S. Blair to be identified as author of this work has been asserted in accordance with the Copyright, Designs and Patents Act 1988.

The Publisher gratefully acknowledges support for the production of this volume from The al-Sabah Collection, Kuwait

Sheikha Hussah Sabah Salem al-Sabah

Co-founder

Publication of this book has been aided by a grant from the Millard Meiss Publication Fund of the College Art Association.

MM 